\title{
pH as a proxy for estimating plant-available Si? A case study in rice fields in Karnataka (South India)
}

\author{
Jean-Dominique Meunier', Kollalu Sandhya ${ }^{2}$, Nagabovanalli B. Prakash ${ }^{2}$, Daniel \\ Borschneck $^{1}$, Philippe Dussouillez ${ }^{1}$, \\ ${ }^{1}$ Aix Marseille Univ. CNRS, IRD, INRA, Coll France, CEREGE, Aix en Provence, France \\ ${ }^{2}$ University of Agricultural Sciences, Dpt of Soil Science \& Agr Chemistry, GKVK, Bengaluru \\ 560065 Karnataka, India
}

\section{Abstract}

Background and aims. Although $\mathrm{Si}$ is recognized as a beneficial element for crops, the determination of plant-available silicon (PAS) in soils has become challenging. A correlation between $\mathrm{pH}$ and PAS indicators has been reported in the literature due to the higher degree of weathering of acidic soil. We tested this hypothesis in the cultivated rice fields of Karnataka State, India, which exhibit gradients of $\mathrm{pH}$ and climate.

Method. Two hundred surface soil samples were collected from rice fields representing nine of the ten agro-climatic zones (ACZs) defined for Karnataka. We analyzed the Si extracted by calcium chloride $\left(\mathrm{Si}_{\mathrm{CC}}\right)$ and the $\mathrm{Si}$ extracted by acetate-acetic acid $\left(\mathrm{Si}_{\mathrm{AA}}\right)$ as PAS indicators. The samples were analyzed for particle size distribution, $\mathrm{pH}$, electrical conductivity and cation exchange capacity. Forty subsamples were selected for mineralogical and chemical analysis. Results. PCA of the 200 samples showed that PAS indicators and $\mathrm{pH}$ were positively correlated. $\mathrm{Si}_{\mathrm{AA}}$ was also positively correlated with electric conductivity (EC), CEC, and the silt fraction and negatively correlated with the sand fraction. A separation of the data arbitrarily made at $\mathrm{pH}$ 7.5 showed that below 7.5, the correlation between PAS indicators and $\mathrm{pH}$ was better than considering the whole 200 samples. The distribution of $\mathrm{Si}_{\mathrm{AA}}$ with $\mathrm{pH}$ matched the curve of adsorbed Si given in the literature. Soils characterized by low $\mathrm{pH}$ and high contents of sand, $\mathrm{SiO}_{2}, \mathrm{Zr}$ and $\mathrm{Hf}$, showed a higher degree of weathering. They were preferentially located along the coast, where the rainfall is the most abundant. The depletion of PAS indicators was also in good agreement with the predominance of kaolinite instead of smectite, which characterizes a higher degree of desilication.

Conclusion. We demonstrated that the correlation between $\mathrm{pH}$ and PAS indicators is explained by natural Si depletion (weathering intensity) and the effect of Si adsorption. We suggest that at $\mathrm{pH}$ values up to $7.5, \mathrm{pH}$ can be used as a proxy for PAS in similar types of pedo-climatic conditions. 
39 Keywords Plant available silicon/ Weathering/ Adsorption/ Rice/ Karnataka State

40

41

42

43

\section{Introduction}

Silicon, the second most common element on the earth's surface, is also present in significant amounts in the shoots of the main crops produced worldwide (Guntzer et al., 2012). It is well established that the accumulation of Si in plants as phytoliths follows the same pathways as for the majority of the nutrients: root uptake from the soil solution (Liang et al., 2015). The speciation of dissolved $\mathrm{Si}$ (DSi) is quite simple because there is almost exclusively only one species below $\mathrm{pH}$ 9: the monomeric silicic acid $\mathrm{H}_{4} \mathrm{SiO}_{4}$. At elevated $\mathrm{pH}, \mathrm{H}_{4} \mathrm{SiO}_{4}$ dissociates into anions to form $\mathrm{H}_{3} \mathrm{SiO}_{4}{ }^{-}$and $\mathrm{H}_{2} \mathrm{SiO}_{4}{ }^{2-}$ (Philippini et al., 2006). The source of DSi is ultimately the soil-forming mineral, which can include quartz, aluminosilicates, phyllosilicates, clay minerals and amorphous silica (Cornelis et al., 2011). However, the soil-forming minerals are largely resistant to weathering (Berner and Berner, 1996). As a consequence, with increasing time, the soil becomes depleted of $\mathrm{Si}$, as evidenced by the "desilication" process (Buol et al., 1989), which shows with increasing weathering intensity the formation of $2 / 1$ clay mineral, $1 / 1$ clay mineral and ultimately only Fe-Al oxyhydroxides (Cornelis et Delvaux, 2016). Evidence of Si leaching by weathering is also documented along soil profiles using mass balance calculations, which show increases in Si loss with soil age (White, 2005; Sommer et al., 2006). Using water analysis, various approaches had similar conclusions. A comparison of DSi concentrations of the continents showed that the highest concentration of DSi occurs in African streams (12.6 $\mathrm{mg} \mathrm{L}^{-1}$ on average), where hot climatic conditions prevail (Dürr et al., 2011). Another example of Si loss during weathering is found in Hawaiian volcanic soil solutions (Derry et al., 2005), where DSi decreases when the age of the soil increases. The content of minerals favorable for weathering for a given soil is therefore a stronger constraint for explaining the accumulation of Si in plants (Henriet et al., 2008).

Despite the abundant literature showing that Si is beneficial for crops (Liang et al., 2015), the bioavailability of Si remains a challenging topic (Haynes, 2014). To quantify the plant-available Si (PAS), various empirical indicators have been proposed (Nayar et al., 1977; Barbosa-Filho et al., 2001; Korndorfer et al., 2001; Narayanaswamy and Prakash, 2010; Yanai et al., 2016; Crusciol et al., 2017). These indicators are based on the use of chemical extractants of DSi from soils that give good correlations with plant Si content or yield. PAS indicators such as $\mathrm{H}_{2} \mathrm{O}, \mathrm{CaCl}_{2}$, acetic acid and acetate may also be useful to identify the soil depleted of PAS and eventually to justify the application of Si fertilizers (Berthelsen et al., 1999). However, the 
use of these PAS indicators is still poorly evaluated because of the lack of studies documenting the Si pools that are controlling them. Indeed, the correlation between PAS indicators and soil acidity, as measured by $\mathrm{pH}$, has been reported in the literature as an indicator of intensity of weathering: lower $\mathrm{pH}$ may be associated with low PAS in highly leached soils (Review in Haynes, 2014 and Liang et al. 2015). For instance, Miles et al. (2014) showed that pH and $\mathrm{CaCl}_{2}$-extractable $\mathrm{Si}\left(\mathrm{Si}_{\mathrm{CC}}\right)$ are correlated in the range of $\mathrm{pH} 3.3$ to $\mathrm{pH} 7$ in the South African sugarcane fields. According to the authors, such a correlation is attributable to a change in mineralogy from a less weatherable pool of Si minerals at low $\mathrm{pH}$ to a more weatherable pool of Si minerals at higher $\mathrm{pH}$, following the conclusion of Henriet et al. (2008). However, in Henriet et al. (2008), the pH range does not differ between desilicated soils and less weathered soils. In addition, Miles et al. (2014) did not document the mineral content/Si status of their studied soils, so other hypotheses are possible to explain the correlation between $\mathrm{pH}$ and PAS indicators. One hypothesis is that PAS is controlled by adsorbed Si. Indeed, it is well documented that $\mathrm{Si}$ adsorption increases with $\mathrm{pH}$ in a similar range as in the previously mentioned study by Miles et al. (2014), specifically if Al and Fe oxides are present (Beckwith and Reeve 1963; Kingston et al., 1972, Philippini et al., 2006; Hiemstra et al., 2007). Another hypothesis is that PAS may be controlled by the soil phytolith pool. Phytoliths are residues of Si accumulated in plants during litter decomposition and are composed of amorphous silica particles, which are considered to be among the most soluble pools of Si in soils (Fraysse et al., 2009). Because plant productivity is generally lower at low $\mathrm{pH}$ due to poor nutrient content and aluminum toxicity (Zheng, 2010), it is possible that a correlation between $\mathrm{pH}$ and PAS could be due to the phytolith content. To decipher the factors that control the PAS and to document whether $\mathrm{pH}$ can be used as a proxy for PAS, our approach here was to combine agronomical, physical, mineralogical and chemical properties of cultivated soils that exhibit a large $\mathrm{pH}$ gradient. Accordingly, we conducted a study in different rice ecosystems corresponding to acidic, slightly acidic, neutral and alkaline soils with distinct climates in the Karnataka State of South India.

\section{Materials and Methods}

The State of Karnataka forms the west central part of Peninsular India. It occupies an area of $1,91,792 \mathrm{~km}^{2}$ and is divided into 4 physiographic regions: 1 . the Northern Karnataka Plateau at 300-600 masl, on the Deccan Traps; 2. the Central Karnataka Plateau at 450-700 masl; 3. the Southern Karnataka Plateau at 600-900 masl, bordered by the Western Ghats in the west and south; and 4. the Karnataka Coastal Region between the Western Ghats in the East and the 
Arabian Sea in the west. The climate varies from tropical wet along the coast to tropical wet and dry to the center and semi arid to the east. The rainfall is profoundly affected by the monsoon season between June and September and shows a gradient from $512 \mathrm{~mm}$ to $4700 \mathrm{~mm}$

111 westward (Fig. 1a). The rainfall has a strong influence on the soil type, with ultisols and alfisols 112 prevailing along the coastal region, aridisols in the Central Karnataka Plateau and vertisols in 113 the Northern Karnataka Plateau (Hajira Sajini and Shivanna, 2017). The parent rocks mainly 114 consist of Archean gneisses, granites and charnockite rocks. Others consist of Proterozoic 115 sedimentary formations, the Deccan basalts (to the North) and Tertiary and Quaternary 116 sediments toward the west coast (Radhakrishnan and Vaidyanadhan, 1997).

117 Two hundred soil samples were collected from rice fields representing nine out of ten agro118 climatic zones (ACZs) defined for Karnataka (Fig. 1b). ACZs serve as focal areas for 119 conducting location-specific research (Ramachandra et al., 2004). ACZs are based on rainfall 120 patterns, topography, soil type, climate and cropping patterns. The sampling was mainly 121 performed after the harvest of rice crops during 2014 and 2015 using an auger sampler to a 122 depth of $0-15 \mathrm{~cm}$ and by recording the coordinates (latitude and longitude) of each location.

123 Basic location information, such as district, taluk, village and cropping system, was also 124 recorded and is presented in Appendix 1. Due to introduction of combine harvesters, most of 125 the farmers are incorporating rice straw to their agricultural fields (rice fields), which otherwise 126 would serve mainly as fodder to cattle. However, rice husk is being used for different purpose, 127 which ranges from serving as fuel source in rice mills, hotels etc., to packing material and also 128 as bedding material in poultry industries.

Approximately 12 - 15 subsamples of 200-300 g were collected from each sampling location using a screw auger and mixed thoroughly to obtain a representative sample. Each 131 representative soil sample was placed in a separate plastic zip-lock cover bag to avoid contamination of the samples. Soil samples were shade dried, powdered and sieved through a 2 $133 \mathrm{~mm}$ mesh sieve and stored in plastic container bottles for further use. The samples were 134 analyzed for particle size distribution (pipette method), $\mathrm{pH}$ (soil-water suspension of 1/2.5), 135 electrical conductivity (E.C., soil-water suspension of 1/2.5), and cation exchange capacity 136 (CEC, for $\mathrm{pH}<8.2$ : distillation method, Page et al., 1982; $\mathrm{pH}>8.2$ : flame photometry, Jackson, 137 1973). The choice of the PAS indicators was based on a critical evaluation of the literature 138 (Sauer et al. 2006; Narayanaswamy and Prakash, 2010; Georgiadis et al., 2013; Haynes, 2014; 139 Miles et al. 2014). We analyzed the Si extracted by $0.01 \mathrm{M} \mathrm{CaCl}_{2}\left(\mathrm{Si}_{\mathrm{CC}}\right.$, Haysom and Chapman, $140 \mathrm{1975}$ ) for the determination of the pool of readily soluble Si and the Si extracted by $0.5 \mathrm{M}$ 141 acetate-acetic acid ( $\mathrm{Si}_{\mathrm{AA}}$, Korndorfer et al., 2001) for the pool of adsorbed Si. These two PAS 
142 indicators were strongly correlated with Si uptake and yields in rice grown on acidic soils 143 originated from Coastal and Hilly zones (Narayanaswamy and Prakash, 2010). We used 144 Quantum GIS (QGIS) 2.14 to map the studied parameters in Karnataka State.

145 Out of 200 samples, 40 representative samples with varied $\mathrm{pH}$ (acidic, neutral and alkaline) and 146 silicon content were selected for chemical and mineralogical studies. The mineralogical 147 composition was measured on bulk samples finely ground using a PANanalytical X'Pert Pro 148 (Cobalt anti-cathode, $\lambda=1.79 \AA$ ) X-ray diffractometer running at $40 \mathrm{kV}$ and $40 \mathrm{~mA}$.

149 The clay composition was determined on oriented plates after destruction of organic matter 150 (using hydrogen peroxide) and carbonate (using hydrochloric acid) and extraction of the clays 151 by Stokes' law. Organic carbon (O.C.) was measured using the chromic acid titration method. 152 Major elements were measured by fusion/XRF, and trace elements were measured by four $153 \mathrm{acid} / \mathrm{ICP}-\mathrm{MS}$ at ALS Minerals, Seville, Spain (http://www.alsglobal.com/Our154 Services/Minerals). We chose to analyze $\mathrm{Zr}$ and Hf because they have refractory properties that 155 can be used to trace the intensity of weathering (Kurtz et al., 2000; Braun et al., 2005). PCA, ANOVA, Student's t test and regressions were calculated using Excel (Microsoft) 157 and Xlstat (Addinsoft).

\section{Results}

Characterization of the 200 samples

The measurements of the 200 samples are detailed in Supplementary Material. The texture of the soils varied from sandy loam to clay. $\mathrm{pH}, \mathrm{EC}, \mathrm{Si}_{\mathrm{CC}}, \mathrm{Si}_{\mathrm{AA}}$, and $\mathrm{CEC}$ ranged from 4.9 to 9.5, 0.02 to $1.07 \mathrm{dSm}^{-1}, 1.4-82.9 \mathrm{mg} \mathrm{kg}^{-1}, 6.7$ to $370.2 \mathrm{mg} \mathrm{kg}^{-1}$ and 9.2 to $115.2 \mathrm{cmol}(\mathrm{p}+) \mathrm{kg}^{-1}$, respectively. The proportions of acidic $(\mathrm{pH}<6.5)$, neutral $(\mathrm{pH} 6.5-7.5)$ and alkaline $(\mathrm{pH}>7.5)$ soils were 40, 14 and $46 \%$, respectively. Overall, the $\mathrm{Si}_{\mathrm{CC}}$ values were lower than the $\mathrm{Si}_{\mathrm{AA}}$ values (Student's t test $<0.05$ ). PCA of the data (Table 1) showed that PAS indicators and $\mathrm{pH}$ were positively correlated. $\mathrm{Si}_{\mathrm{AA}}$ was also positively correlated with $\mathrm{EC}, \mathrm{CEC}$, and the silt fraction and negatively correlated with the sand fraction. A closer analysis of the relation between $\mathrm{pH}$ and PAS indicators (Fig. 2) showed that the correlation identified in the PCA may not be a simple linear regression. Indeed, models such as polynomial regressions presented a

173 better fit than a linear regression and showed that the PAS indicators may decrease (for $\mathrm{Si}_{\mathrm{AA}}$ ) 174 or remain stable (for $\mathrm{Si}_{\mathrm{CC}}$ ) where $\mathrm{pH}>7.5$. A separation of the data arbitrarily made at $\mathrm{pH} 7.5$ 175 showed that below 7.5, the correlation between PAS indicators and $\mathrm{pH}$ was better than 
considering the whole 200 samples with best fits using power regression models. ANOVA of

177 the soil categories showed that the ultisol and alfisol samples had both the lowest $\mathrm{pH}$ while the 178 vertisol samples have the highest CEC values (Table 2). Ultisol and alfisol present the lowest 179 PAS indicators but they are not significantly different from all soils for SiCC (except Aridisol) and from all soils for SiAA (except Entisol and Vertisol) Plotting the data into the Karnataka map showed a general trend of lower $\mathrm{pH}$ and PAS indicators towards the west coast, which is represented by the hilly and coastal zones (Fig. 3).

Mineralogy and geochemistry of the 40 samples

Quartz, feldspars, amphibole, goethite, gibbsite, Ti oxides and phyllosilicates were the main minerals identified in most of the samples (Table 3). Gibbsite was more frequent in the coastal zone. Calcite has been detected in 4 samples (number 2, 54, 97 and 157). The clay minerals identified included smectite, chlorite, vermiculite, illite, kaolinite, and various interlayers of illite-smectite and chlorite-vermiculite. Smectite has not been identified in the hilly and coastal zones, where kaolinite seemed to be the dominant clay. The chemistry was dominated by $\mathrm{SiO}_{2}$ (55-88 \%), $\mathrm{Al}_{2} \mathrm{O}_{3}(5-18 \%), \mathrm{Fe}_{2} \mathrm{O}_{3}(2-16 \%), \mathrm{CaO}(0.1-9 \%), \mathrm{K}_{2} \mathrm{O}(0.1-4.5 \%)$. PCA analysis (Fig. 4a) showed that both PAS indicators were significantly positively correlated with $\mathrm{Al}_{2} \mathrm{O}_{3}$. However, $\mathrm{Si}_{\mathrm{AA}}$ was also significantly positively correlated with $\mathrm{pH}, \mathrm{Fe}_{2} \mathrm{O}_{3}, \mathrm{MgO}, \mathrm{MnO}$ and negatively correlated with $\mathrm{SiO}_{2}$, $\mathrm{Hf}$ and $\mathrm{Zr}$. Using our 40 subsamples, the correlation between $\mathrm{Si}_{\mathrm{CC}}$ and $\mathrm{pH}$ became non significant $(\mathrm{R}=0.3$, figure $4 \mathrm{a})$. However if we select only the samples where $\mathrm{pH}$ is $<7.5$, we obtained a significant correlation $(\mathrm{R}=0.4, \mathrm{n}=24, \mathrm{P}=0.05)$, as shown in figure 2. Projections of the two most predominant variables (F1 and F2) in the principal component space (Fig. 4b) showed that both PAS indicators are grouped at a pole constituted by $\mathrm{pH}, \mathrm{Al}_{2} \mathrm{O}_{3}, \mathrm{Fe}_{2} \mathrm{O}_{3}, \mathrm{MgO}, \mathrm{TiO}_{2}, \mathrm{MnO}, \mathrm{P}_{2} \mathrm{O}_{5}$ and $\mathrm{CaO}$ to the left and are opposed to a group constituted by $\mathrm{SiO}_{2}, \mathrm{~K}_{2} \mathrm{O}, \mathrm{Na}_{2} \mathrm{O} \mathrm{Zr}$ and $\mathrm{Hf}$ to the right. Organic carbon was only positively correlated with $\mathrm{P}_{2} \mathrm{O}_{5}$.

\section{Discussion}

PAS indicators and the soil weathering state

The range of $\mathrm{Si}_{\mathrm{CC}}$ falls in the same range as in previous studies, particularly for acidic rice field soils in Karnataka State (Narayanaswamy and Prakash, 2009) and for sugarcane fields in 
210 Maharashtra state, India (Phonde et al., 2014). The range of $\mathrm{Si}_{\mathrm{AA}}$ is in good agreement with the

211 results of Naryanaswamy and Prakash (2009) but falls in the lower range of the sugarcane fields

212 published by Phonde et al. (2014). The $\mathrm{Si}_{\mathrm{AA}}$ values are slightly more elevated than the $\mathrm{Si}_{\mathrm{CC}}$

213 values, as previously shown in the literature (Narayanaswamy and Prakash 2009; Hohn et al.,

214 2008), confirming that the two chosen PAS indicators do not cover the same Si pools in soils.

215 The positive correlation between $\mathrm{Si}_{\mathrm{AA}}$ and $\mathrm{Si}_{\mathrm{CC}}$ is also in good agreement with previous studies

216 (de Lima-Rodriguez et al., 2003), showing that the pools extracted by the two PAS indicators

217 are not independent and that the fraction of Si extracted by calcium chloride is also included in

218 the fraction of Si extracted by acetic acid.

219 By combining physical (grain size), chemical and mineralogical data, our results show

220 that soils that are low in PAS indicators are those characterized by low $\mathrm{pH}$ and by higher

221 contents of sand (Table 1), $\mathrm{SiO}_{2}, \mathrm{Zr}$ and $\mathrm{Hf}$ (Fig. 4), all parameters that may indicate a higher

222 degree of weathering. Higher content of sand and $\mathrm{SiO} 2$ is interpreted as the quartz contribution

223 in acidic weathered soils. Acidic weathered soils are preferentially located along the coast,

224 where the rainfall is the highest (Fig. 1a). The depletion of PAS indicators is also in good

225 agreement with the predominance of kaolinite instead of smectite, which characterizes a higher

226 degree of desilication (Cornelis and Delvaux, 2016).

227 Accordingly, our results demonstrate that higher weathering and desilication lead to the 228 depletion of PAS indicators, as previously suggested by some authors (Winslow et al., 1997;

229 Bethelsen et al., 1999; Miles et al., 2014; Tavakoli et al., 2011). CEC was not significantly

230 lower in the ultisols and alfisols, contrary to what is shown elsewhere, where low pH means

231 low soil exchangeable bases (Maire et al., 2015). Such a discrepancy may be due to a flaw in

232 soil categorization or may result from perturbation due to agricultural practice (addition of $\mathrm{N}$,

233 P, K fertilization, for instance). The level of Si extracted by either calcium chloride or acetic

234 acid depends on the complex interaction of molecules at the mineral-water interface and may

235 be controlled by dissolution (Dove, 2006) and/or by desorption (Hiemstra et al., 2007).

237 PAS controlled by dissolution

239 The good correlation between $\mathrm{pH}$ and PAS indicators up to $\mathrm{pH} 7.5$ is in good agreement with 240 the results of Miles et al. (2014) from sugarcane fields in South Africa. Miles et al. (2014) 241 attributed this correlation to a change of minerals controlling the solubility of Si when $\mathrm{pH}$ 242 increases: kaolinite at the lowest $\mathrm{pH}$ and more soluble aluminosilicate minerals such as feldspar 243 or smectite at higher $\mathrm{pH}$. Such a hypothesis is supported by our XRD data because kaolinite 
seems to be the major clay minerals in the Coastal Zone; however, those soils are not totally

245 depleted of feldspar, and amphibolite and other clay minerals are present. Accordingly, soils located in most weathered zones from Karnataka are not totally depleted of weatherable Si minerals (aluminosilicates) that can be potential sources of dissolved Si (DSi). Because those highly weathered soils are also enriched in quartz, it is likely that the low PAS may be attributable to the low proportion of weatherable minerals. In addition, if PAS indicators mimic the amount of dissolved Si from the soil mineral, values may not necessarily increase with $\mathrm{pH}$ because the dissolution rates of aluminosilicate minerals follow a $\mathrm{V}$-shaped pattern with a minimum at $\mathrm{pH}$ values of approximately 7-8 (Fraysse et al., 2009), contradicting our data, which show a linear increase or a bell curve, specifically for $\mathrm{Si}_{\mathrm{AA}}$ (Fig. 2). The $\mathrm{pH}$ increase with PAS indicators may otherwise be explained by the kinetics of silica mineral dissolution. Indeed, rates of quartz and phytolith dissolution are known to increase regularly from $\mathrm{pH} 4$ to $\mathrm{pH} 9$ (Fraysse et al., 2009; Dove, 2006). Here, an increase in PAS indicators is observed up to $\mathrm{pH}$ values of approximately 7 , as it should be observed if silica particles (quartz and phytoliths) are controlling PAS. However, dissolution of quartz is a slow process, and we can assume that the contribution of quartz to explaining the PAS indicators is limited below $\mathrm{pH}$ 7.5. It is well documented that soil organic carbon (OC) and phytolith content can be well correlated in natural ecosystems (Alexandre et al., 1997, 2011), but we did not analyze the phytolith composition of the soils. We found no significant correlation between OC and PAS indicators (Fig. 4). Hence, if we postulate that soil $\mathrm{OC}$ is a proxy for phytoliths, we can suggest that $\mathrm{Si}_{\mathrm{CC}}$ and $\mathrm{Si}_{\mathrm{AA}}$ indicators were not significantly controlled by phytolith dissolution. Based on the solubility and dissolution properties of phytoliths (Fraysse et al., 2009), it is unlikely that the protocols that we used (non alkaline solutions for 16h) would be favorable to a significant dissolution of phytoliths. Therefore, new protocols should be tested to evaluate the role of the phytolith pool as controling PAS.

PAS controlled by desorption

Alternatively, PAS indicators are controlled by the adsorption of Si on the surfaces of soil material. Adsorption is, however, a complex mechanism (Manceau et al., 2002) that includes physisorption, chemisorption, organo-mineral complexation, and complexation to bacteria. Although the adsorption of $\mathrm{Si}$ on organics and bacteria in soils has not yet been demonstrated, the adsorbed Si on minerals seems to follow a double layer structure with an 
278 (Hiemstra et al., 2007). The physisorbed molecules are retained by electrostatic interactions and 279 correspond to the exchangeable fraction also measured by the CEC. The chemisorbed fraction is linked to the surface by sharing one or several ligands (like $\mathrm{O}$ ) of the molecule and the sorbent.

281 To explore whether the PAS indicators are extracting Si that is adsorbed from DSi originating 282 from the dissolution of soil particles, the correlation between PAS indicators and chemistry can 283 be helpful. Indeed, $\mathrm{Si}_{\mathrm{AA}}$ positively correlated with $\mathrm{Al}_{2} \mathrm{O}_{3}, \mathrm{Fe}_{2} \mathrm{O}_{3}, \mathrm{MgO}$ and $\mathrm{MnO}$, which 284 indicates that this extractant assesses the fraction of $\mathrm{Si}$ adsorbed on the surface of 285 oxides/oxihydroxides of Fe and Al (Hiemstra et al., 2007) as well as clays (Georgadis et al., 2013; Nguyen et al., 2017) or other Mg-bearing silicate minerals such as amphibole.

$\mathrm{Si}_{\mathrm{CC}}$ is generally lower than $\mathrm{Si}_{\mathrm{AA}}$ which suggests that the calcium chloride extractant gives preferential access to the physisorbed $\mathrm{Si}$, while the acetic acid extractant gives access to physisorbed and chemisorbed Si. The solvent capacity of the acetic acid extractant can be explained by the following reaction:

$$
\mathrm{CH}_{3} \mathrm{CO}_{2} \mathrm{H} \rightarrow \mathrm{CH}_{3} \mathrm{CO}_{2}^{-}+\mathrm{H}^{+}
$$

The release of protons gives its acidic character, which explains why the acetic acid extractant has a more powerful extracting capacity than the $\mathrm{CaCl}_{2}$ extractant. If the extractant solutions are able to dissolve the Si that is chemisorbed on the soil mineral surfaces, a positive correlation with increasing $\mathrm{pH}$ similar to the correlation observed in the experiment of $\mathrm{Si}$ adsorption as a function of $\mathrm{pH}$ is expected. Our data show that the correlation of $\mathrm{pH}$ with $\mathrm{Si}_{\mathrm{AA}}$ gives a much better match than the correlation with $\operatorname{Si}_{\mathrm{CC}}$ (Fig. 2). Accordingly, the acetic acid procedure is a better approach than the calcium chloride procedure to estimate the Si pool that is chemically sorbed.

The increased adsorption of Si with $\mathrm{pH}$ increasing shows quite similar maximum values according to the material involved: approximately 9 for clay minerals (Nguyen et al., 2017); between 9 and 10 in an acid brown forest soil from Wales (Obihara and Russell, 1972), between

3059 and 10 on goethite and gibbsite (Hingston et al., 1972) and between 7 and 10 on $\mathrm{Al}$ and Fe sesquioxides (Beckwith and Reeve, 1963). Here, a maximum around $\mathrm{pH} 8$ may be seen using our polynomial regression model for $\mathrm{Si}_{\mathrm{AA}}$ data in fairly good agreement with the $\mathrm{Si}$ adsorption experiments (Fig. 2). Indeed, the shape of the polynomial curve found for $\mathrm{Si}_{\mathrm{AA}} \mathrm{vs}$. pH (Fig. 2) looks very similar to the curve of the percentage of Si adsorption on goethite and siderite given by Philippini et al. (2006). Si adsorption with $\mathrm{pH}$ up to 9 can be explained by the interaction of 
312 of $\mathrm{Si}$ with the protonated surface implies a release of protons after adsorption. The $\mathrm{Si}$ at the

313 surface forms species such as Fe oxide-monosilicate bi-dentate complexes on iron oxides

314 (Hiemstra et al., 2007). Therefore, the lower the $\mathrm{pH}$ (the higher the presence of protons) is, the

315 higher the chance to desorb Si.

317 Application in Si fertilization

319 The PAS indicators used in the cultivated surface soils in Karnataka are therefore controlled both by the solubility of soil silicate minerals and sorption mechanisms. Narayanaswamy and Prakash (2009) used pot experiments with south Indian soils fertilized with silicates to estimate the critical level of PAS based on the procedure of Cate and Nelson (1971). Briefly, in a plot of a laboratory test (here PAS indicators in abscissa) vs yield (ordinate), critical level is the vertical line that divide the population into 2 categories (high probability of response and low probability of response). Below the critical level, Si is considered deficient and will probably

326 limit crop yield. Narayanaswamy and Prakash (2009) also found that the critical levels using

$327 \mathrm{Si}_{\mathrm{AA}}$ and $\mathrm{Si}_{\mathrm{CC}}$ were 54 and $43 \mathrm{mg} \mathrm{kg}^{-1}$, respectively. Applying those critical levels to our data shows that approximately 88 and 38 percent of the total soil samples were categorized as depleted of PAS as extracted by calcium chloride and acetic acid, respectively. A closer look at the coastal and hilly zones, where alfisols are dominant, shows that nearly 90 and 82 percent of the soils are depleted of PAS as extracted by calcium chloride and acetic acid, respectively. To improve Si uptake and yield in acidic soils, several modalities of fertilization may be recommended: liming, which may lead to enhanced PAS by increasing $\mathrm{pH}$; Si fertilization; or both modalities. Because PAS indicators increase with $\mathrm{pH}$, liming of highly acidic soils may be enough to enhance the delivery of $\mathrm{Si}$ in the soil solutions, assuming that PAS is controlled by adsorption/desorption processes. However, our data show that extremely acidic soils are also those that are the most enriched in quartz and kaolinite, which are the least favorable Si source for DSi. Hence, the addition of lime alone will not be favorable for increasing PAS, contrary to what may be concluded from the graphs in Fig. 2 alone if the mineralogical composition is not given. Another practical application of this study is that a simple measure of $\mathrm{pH}$ can be used as a proxy for PAS using the equations presented in Fig. 2, for $\mathrm{pH}$ values up to 7.5.

\section{Conclusion}


345 Our results show that soils that are low in PAS indicators are the acidic soils that are common

346 along the coastal zone, where rainfall is the highest. The acidic soils are characterized by higher 347 contents of quartz, $\mathrm{Zr}$ and $\mathrm{Hf}$, all parameters indicating a higher degree of weathering. The 348 depletion of PAS indicators is also in good agreement with the predominance of kaolinite, which 349 characterizes a higher degree of desilication. The positive correlation of $\mathrm{pH}$ with PAS indicators 350 is also compatible with the adsorption of $\mathrm{Si}$, which depends ultimately on the amount of $\mathrm{Si}$ 351 source available in the soil. We suggest that $\mathrm{pH}$ measurements may be useful as a proxy for 352 PAS.

Acknowledgement This work was financed by the Indo-French Centre for the Promotion of Advanced Research (IFCPAR/CEFIPRA project $n^{\circ} 5109-1$ ). The authors wish to thank Jules Fleury and Yves Lucas for their helpful contributions.

\section{References}

Alexandre A, Meunier JD, Colin F, Koud JM (1997) Plant impact on the biogeochemical cycle of silicon and related weathering processes, Geochim. et Cosmochim. Acta, 61, 677682.

Barbosa-Filho MP, Snyder GH, Elliott CL, Datnoff LE (2001) Evaluation of soil test procedures for determining rice-available silicon. Commun. Soil Sci. Plant Anal 32, 1779-1792.

Beckwith RS, Reeve R (1963) Studies on soluble silica in soils. I. The sorption of silicic acid by soils and minerals. Aust. J. Soil Res., 1 157-168.

Berner EK, Berner RA (1996) Global environment: water, air, and geochemical cycles. Printice Hall, Upper Saddle River, New Jersey.

Berthelsen S, Noble AD, Garside AL (1999) An assessment of soil and plant silicon levels in North Queensland. Proc. Aust. Soc. Sugar Cane Technol. 21, 92-100. University/Ames, 445p. 
Cate RB Jr, Nelson LA (1971) A simple statistical procedure for partitioning soil test correlation data into two classes. Soil Science Society America Journal 35: 658-660

Cornelis JT, Delvaux B, Georg RB, Lucas Y, Ranger J, Opfergelt S (2011) Tracing the origin of dissolved silicon transferred from various soil-plant systems towards rivers: a review. Biogeosciences 8, 89-112.

Cornelis JT, Delvaux B (2016) The functional role of silicon in plant biology. Soil processes drive the biological silicon feedback loop. Functional Ecology 30, 1298-1310.

Crusciol CAC, de Arruda DP, Fernandes AM, Antonangelo JA, Alleoni LRF, do Nascimento CAC, Rossato OB, McCray JM (2017) Methods and extractants to evaluate silicon availability for sugarcane. Scientific reports 8:916, DOI:10.1038/s41598-018-19240-1.

De Lima-Rodriguez L, Daroub SH, Rice RW, Snyder GH (2003) Comparison of three soil test methods for estimating plant-available silicon. Comm. Soil Sci. Plant Anal. 34, 20592071 .

Derry LA, Kurtz AC, Ziegler K, Chadwick OA (2005) Biological control of terrestrial silica cycling and export fluxes to watersheds. Nature, 433, 728-731.

Dove PM (2006) Kinetic and thermodynamic controls on silica reactivity in weathering environments. In "Chemical weathering rates of silica minerals", Review in Mineralogy 31, White AF, Brantley SL, eds, 235-290, Mineralogical Society of America.

Dürr HH, Meybeck M, Hartmann J, Laruelle GG, Roubeix V (2011) Global spatial distribution of natural riverine silica inputs to the coastal zone. Biogeosciences 8, 5978-620

Fraysse F, Pokrovsky OS, Schott J, Meunier JD (2009) Surface Chemistry and reactivity of plant phytoliths in aqueous solutions, Chemical Geology, 258, 197-206

Georgiadis A, Sauer D, Herrmann L, Breuer J, Zarei M, Stahr K (2013) Development of a method for sequential Si extraction from soils. Geoderma 209-210, 251-261.

Guntzer F, Keller C, Meunier JD (2012) Benefits of plant silicon for crops : a review. Agron Sust. Dev. 32, 201-213.

Hajira Sajini S, Shivanna (2017) Soil mapping and classification using remote sensing and GIS in Sullia Taluk, DK, Karnataka, India. Int. J. Innov. Res. Sci. Eng. Tech. 6, DOI:10.15680/IJIRSET.2017.0609077

Haynes RJ (2014) A contemporary overview of silicon availability in agricultural soils. J. Plant Nutr. Soil Sci. 177, 831-844.

Haysom MBC, Chapman LS (1975) Some aspects of the calcium silicate trials at Mackay. Proc. Qld. Soc. Sugar Cane Technol. 42, 117-122. 
Henriet C, Bodarwé L, Dorel M, Draye X, Delvaux B (2008) Leaf silicon content in banana (Musa spp.) reveals the weathering stage of volcanic ash soils in Guadeloupe. Plant Soil 313: 71-82.

414 Hiemstra T, Barnett MO, van Riemsdijk WH (2007) Interaction of silicic acid with goethite. J Colloid Interface Sci. 310, 8-17.

Hingston FJ, Posner AM, Quirk JP (1972) Anion adsorption by goethite and gibbsite. I. The role of the proton in determining adsorption envelopes. J. Soil Sci. 23, 177-192.

Hohn A, Sommer M, Kaczorek D, Schalitz G, Breuer J (2008) Silicon fractions in histosols and gleysols of a temperate grassland site. J. Plant Nutr. Soil Sci. 171, 409-418.

Jackson ML (1973) Soil chemical analysis. Printice Hallof India Pvt. Ltd.New Delhi.

Korndorfer GH, Snyder GH, Ulloa M, Datnoff LE (2001) Calibration of soil and plant silicon for rice production. Journal of Plant Nutrition 24:1071-1084.

Kurtz AC, Derry LA, Chadwick OA, Alfano MJ (2000) Refractory element mobility in volcanic soils. Geology 28, 683-686.

Liang Y, Nikolic M, Bélanger R, Gong H, Song A (2015) Silicon in agriculture: from theory to practice. Springer, 235p.

Maire V, Wright IJ, Prentice C., Batjes NH, Bhaskar R, van Bodegon PM, Cornwell WK (2015) Global effects of sol and climate on leaf photosynthetis traits and rates. Global Ecol. Biogeogr. DOI: 10.1111/geb.12296

Manceau A, Marcus MA, Tamura N. (2002) Quantitative speciation of heavy metals in soils and sediments by synchrotron X-ray techniques, in Applications of synchrotron

Miles N, Manson AD, Rhodes R, Van Antwerpen R, Weigel A (2014) Extractable silicon in soils of the South African industry and relationships with crop uptake. Comm. Soil Sc. Pl. Anal. 45, 2949-2958.

Nayar PK, Misra AK, Patnaik S (1977) Evaluation of silica-supplying power of soils for growing rice. Plant and Soil 47, 487-494.

Narayanaswamy C, Prakash NB (2009) Calibration and Categorization of Plant Available Silicon in Rice Soils of South India. J of P1. Nutrition 32:8,1237-1254

Narayanaswamy C, Prakash NB (2010) Evaluation of selected extractants for plant-available silicon in rice soils of Southern India. Comm. Soil Sc. Pl Anal., 41, 977-989. 
Nguyen MN, Picardal F, Dultz S, Dam TTN, Nguyen AV, Nguyen KM (2017) Silicic acid as a dispersibility enhanced in a Fe-oxide-rich kaolinitic soil clay. Geoderma 286, 8-14. et al., 2017

Obihara CH, Russell EW (1972) Specific adsorption of silicate and phosphate by soils. J. of Soil Science 23, 105-117.

Page AL, Mille RH, Keeney DR (1982) Methods of soil analysis. $2^{\text {nd }}$ edition. Am. Soc. Agron., Madison, WI, USA.

Philippini V, Naveau A, Catalette H, Leclercq S (2006) Sorption of silicon on magnetite and other corrosion products of iron. J. of Nuclear Mat. 348, 60-69.

Phonde DB, Deshmukh PS, Banerjee K, Adsule PG (2014) Plant available silicon in sugarcane soils and its relationship with soil properties, leaf silicon and cane yield. An Asian Journal of Soil Sci. et al., DOI : 10.15740/HAS/AJSS/9.2/176-180

Prakash NB, Narayanaswamy C, Hanumantharaju TH (2010) Effect of calcium silicate as a silicon source on growth and yield of rice in different acid soils of Karnataka, Southern India. IRRN, 0117-4185

Ramachandra TV, Kamakshi G, Shruti BV (2004) Bioressource status in Karnataka. Renewable and Sustainable Energy Reviews 8, 1-47.

Radhakrishnan BP, Vaidyanadhan R (1997) Geology of Karnataka, Geological Society of India, Bangalore, Ind

Sauer D, Saccone L, Conley DJ, Herrmann L, Sommer M (2006). Review of methodologies for extracting plant-available and amorphous $\mathrm{Si}$ from soils and aquatic sediments. Biogeochemistry, 80, 89-108

Savant NK, Datnoff LE, Snyder GH (1997) Depletion of plant-available silicon in soils: a possible cause of declining rice yields. Comm. Soil Sci. Plant Anal 28, 1245-1252.

Sommer M, Kaczorek D, Kuzyakiv Y, Breuer J (2006) Silicon pools and fluxes in soils and landscapes-a review. J. Plant Nutr. Soil Sci. 169, 310-329.

Tavakoli E, Lyons G, English P, Guppy CN (2011) Silicon nutrition of rice is affected by soil pH, weathering and silicon fertilization. J. Plant Nutr. Soil Sci. 174, 437-446

Winslow MD, Okada K, Correa-Victoria F (1997) Silicon deficiency and the adaptation of tropical rice ecotypes. Plant and Soil 188, 239-248.

White AF (2005) Natural weathering rates of silicate minerals. In Treatise on Geochemistry vol 5, "Surface and ground water, weathering, and soils", Drever JI ed, 133-168 (Elsevier). Yanai J, Taniguchi H, Nakao A (2016) Evaluation of available silicon content and its determining factors of agricultural soils in Japan. Soil Sci. P1. Nutr. 62, 511-518. 
478 Zheng SJ (2010) Crop production on acidic soils: overcoming aluminium toxicity and 479 phosphorus deficiency. Annals of Botany 106, 183-184. 
482 Figure 1. Location of the 200 studied samples in the (a) rainfall map and (b) Agroclimatic Zones 483 (ACZ) of the Karnataka State (Karnataka State Remote Sensing Applications Center, used by 484 permission); the white circles are the 40 subsamples out of 200 used for chemical and 485 mineralogical studies.

486

487

Figure 2. Correlations between $\mathrm{pH}$ and plant available silicon (PAS) indicators ( $\mathrm{Si}$ AA and $\mathrm{Si}$ cC) for the 200 studied samples.

Figure 3. Variation of PAS indicators a) $\mathrm{Si}_{\mathrm{AA}}$ in $\mathrm{mg} \mathrm{kg}^{-1}$, b) $\mathrm{Si}_{\mathrm{CC}}$ in $\mathrm{mg} \mathrm{kg}^{-1}$ and c) $\mathrm{pH}$, categorized as low, medium and high in the studied area.

492

493

Figure 4. PCA of a subsample of 40 soils showing the correlation between $\mathrm{pH}$, PAS indicators ( $\mathrm{Si}_{\mathrm{AA}}$ in $\mathrm{mg} \mathrm{kg}^{-1}$ and $\mathrm{Si}_{\mathrm{CC}}$, in $\mathrm{mg} \mathrm{kg}^{-1}$ ) and chemical elements (in w.t.\% except $\mathrm{Hf}$ and $\mathrm{Zr}$ in $\left.\mathrm{mg} \mathrm{kg}{ }^{-1}\right)$ : a) correlation matrix (Pearson (n); values in bold are different from 0 with a significance level alpha $=0.05)$; b) projection of the variables in factor 1 and 2 .

\section{List of tables}

500

Table 1. Correlation matrix using PCA (Pearson (n); values in bold are different from 0 with a

502 significance level alpha $=0.05)$ for $\mathrm{pH}$, PAS indicators $\left(\mathrm{Si}_{\mathrm{AA}}\right.$ in $\mathrm{mg} \mathrm{kg}^{-1}$ and $\mathrm{Si} \mathrm{CC}$, in $\mathrm{mg} \mathrm{kg}^{-}$

$503^{1}$ ) and other parameters (E.C. : electric conductivity in $\mathrm{dSm}^{-1}$; $\mathrm{CEC}$ in $\mathrm{cmol}(\mathrm{p}+) \mathrm{kg}^{-1}$; sand, 504 silt and clay fractions in w.t. \%) for the 200 studied samples.

Table 2 Anova using Fischer (LSD)'s test showing the variability between soil categories for 507 the following parameters: a) $\mathrm{pH}, \mathrm{b}) \mathrm{CEC}$ in $\mathrm{cmol}(\mathrm{p}+) \mathrm{kg}^{-1}$ and the PAS indicators c) Si $\mathrm{CC}$ in $508 \mathrm{mg} \mathrm{kg}^{-1}$ and d) $\mathrm{Si}_{\mathrm{AA}}$ in $\mathrm{mg} \mathrm{kg-1}$; number of samples for each soil category is: alfisol = 106, 509 vertisol $=41$, inceptisol $=23$, aridisol $=14$, ultisol $=9$ and entisol $=5$; different letters indicate 510 that the means are statistically different at the $\mathrm{P} \leq 0.05$ level.

512 Table 3. Mineralogical (XRD) and chemical composition of the 40 selected soils from the 7 513 ACZ. 